\title{
High-latitude environmental change during MIS 9 and 11: biogeochemical evidence from Lake El'gygytgyn, Far East Russia
}

\author{
R. M. D'Anjou, J. H. Wei, I. S. Castañeda, J. Brigham-Grette, S. T. Petsch, and D. B. Finkelstein \\ Climate Systems Research Center and Department of Geosciences, University of Massachusetts Amherst, Amherst, \\ MA 01003, USA
}

Correspondence to: R. M. D’Anjou (rdanjou@geo.umass.edu)

Received: 17 August 2012 - Published in Clim. Past Discuss.: 28 September 2012

Revised: 1 February 2013 - Accepted: 6 February 2013 - Published: 8 March 2013

\begin{abstract}
Marine isotope stages (MIS) 11 has been proposed as an analog for the present interglacial; however, terrestrial records of this time period are rare. Sediments from Lake El'gygytgyn $\left(67^{\circ} 30^{\prime} \mathrm{N}, 172^{\circ} 5^{\prime} \mathrm{E}\right)$ in Far East Russia contain a 3.56 Ma record of climate variability from the Arctic. Here, we present the first terrestrial Arctic reconstruction of environmental and climatic changes from MIS 8 through 12 (289 to $464 \mathrm{ka}$ ) using organic geochemical proxies. Terrestrial vegetation changes, as revealed by plant leaf wax ( $n$-alkane) indices and concentrations of arborinol (a biomarker for trees), show increased tree cover around the lake during interglacial periods, with higher concentrations observed during MIS 11 as compared to MIS 9. A similar pattern is also observed in records of aquatic productivity revealed by molecular indicators from dinoflagellates (dinosterol), eustigmatophyte algae (long-chain $\left(\mathrm{C}_{28}-\mathrm{C}_{32}\right) 1,15 n$-alkyl diols) in addition to short-chain $n$-alkanes, where aquatic productivity is highest during MIS 11. Changes recorded in these molecular proxies show a similar structure to relative temperature variability as recorded by the MBT/CBT (Methylation of Branched Tetraether/Cyclization of Branched Tetraether) paleothermometer, based on branched glycerol dialkyl glycerol tetraethers (GDGTs). Additionally, relative MBT/CBT temperature changes generally track pollen and diatom $\delta^{18} \mathrm{O}$ temperature estimates, compiled by other studies, which suggest glacial-interglacial temperature changes of $\sim 9$ to $12^{\circ} \mathrm{C}$. These records of environmental and climatic change indicate Arctic sensitivity to external forcings such as orbital variability and atmospheric greenhouse gas concentrations. Overall, this study indicates that organic geochemical analyses of the Lake El'gygytgyn sediment archive can provide critical insight into the response of lake ecosystems and their sensitivity in high latitude regions.
\end{abstract}

\section{Introduction}

Marine isotope stage (MIS) 11 has been proposed as an ana$\log$ to modern climate conditions, with orbital configurations similar to today and greenhouse gas concentrations at preindustrial levels (Loutre and Berger, 2002; EPICA community members, 2004). Past studies indicate that MIS 11 was one of the warmest and longest interglacial periods of the past $5 \mathrm{Ma}$. The characteristics of this "super" interglacial (Melles et al., 2012) period have been expressed globally in North Atlantic marine sediment core records (Voelker et al., 2010; Lawrence et al., 2009), as well as in Asian lacustrine sedimentary records from Lake Baikal, which indicate a prolonged interglacial period of $\sim 30 \mathrm{kyr}$ (Prokopenko et al., 2010). However, terrestrial records from high latitude regions of the Asian continent are almost non-existent, yet can play a crucial role in understanding aspects of the climate system that currently are not well characterized. The sediment record obtained from Lake El'gygytgyn in Far East Arctic Russia contains a continuous archive of climate variability since the middle Pliocene and permits critical analysis of the structure, and corresponding response of this western Beringian ecosystem to changes during the MIS 11 "super" interglacial period.

The interval spanning MIS stages 9 through 12 is of particular interest to paleoclimatic studies as higher magnitude glacial-interglacial transitions, such as the MIS 12 to MIS 11 (Termination V) transition, was of larger magnitude when compared to previous glacial-interglacial transitions (EPICA community members, 2004). During the peak warmth of MIS 11, global sea levels are understood to have been significantly higher than other interglacials over the past $400000 \mathrm{yr}$ possibly due to significant collapse of both 
the Greenland ice sheet and the West Antarctic Ice Sheet (Raymo and Mitrovica, 2012). This interval, known as the mid-Bruhnes transition, marks a period when the amplitude of interglacial-glacial variability increases following $\sim 430$ ka. Furthermore, past studies on Lake El'gygytgyn sediments by Melles et al. (2012), label MIS 11c as a "super" interglacial where lake sediments reflect high diatom and terrestrial plant productivity.

In this study we examine biogeochemical processes in Lake El'gygytgyn during the period of MIS 9 through 11 (289 to $464 \mathrm{ka}$ ) using multiple organic geochemical-based proxies. Specifically, this study uses organic biomarkers in lake sediments as proxies for reconstructing changes in past environmental conditions. Here, we estimate relative temperature changes using the MBT/CBT (Methylation of Branched Tetraether/Cyclization of Branched Tetraether) paleothermometer (Table 1), which relates changes in the degree of methylation and cyclization of branched glycerol dialkyl glycerol tetraethers (brGDGTS) to mean annual air temperature and $\mathrm{pH}$ (Weijers et al., 2007b). Compounds specific to trees and aquatic organisms demonstrate variability in terrestrial vegetation and aquatic inputs through time, and show responses to changing climate regimes. Finally, our record is comparable to published records from both marine and terrestrial settings, fitting the Lake El'gygytgyn record into a global context. This paper complements the focused summary of other proxies from MIS 11 reviewed by Vogel et al. (2012).

\section{Background information}

\subsection{Lake catchment and site description}

Lake El'gygytgyn is located in the Chukotka Peninsula in the Far East Russian Arctic $\left(67^{\circ} 30^{\prime} \mathrm{N}, 172^{\circ} 5^{\prime} \mathrm{E}\right)$ (Fig. 1). The catchment area sits in an impact structure formed at $3.58 \pm 0.04 \mathrm{Ma}$ (Layer, 2000), with a rim-to-rim diameter of $18 \mathrm{~km}$ and a catchment area of approximately $293 \mathrm{~km}^{2}$ (Nolan and Brigham-Grette, 2007). A network of 50 streams carries surface runoff into the lake, and the Enmyvaam River serves as the outlet to the Bering Sea (Nolan and BrighamGrette, 2007). Lake El'gygytgyn is seated within the bottom of this crater, and is $12 \mathrm{~km}$ wide and $175 \mathrm{~m}$ deep with an approximate volume of $14.1 \mathrm{~km}^{3}$ (Nolan and BrighamGrette, 2007). The lake is an oligotrophic and monomictic lake, with modern lake temperatures which do not exceed $4^{\circ} \mathrm{C}$ and with annual overturning in late summer (Nolan and Brigham-Grette, 2007). Lake ice formation occurs by October, and persists to July.

Modern air temperatures at the lake range from $-46^{\circ} \mathrm{C}$ in the winter to as high as $+26^{\circ} \mathrm{C}$ in summer with a mean annual temperature of $-10.3^{\circ} \mathrm{C}$ (Nolan and Brigham-Grette, 2007). Precipitation levels are generally low, with cumulative precipitation from 2002 to 2007 ranging from 70 to $200 \mathrm{~mm}$
(Nolan, 2012). Strong winds also affect the El'gygytgyn area, with dominant directions out of the north or south and strongest winds in winter (Nolan and Brigham-Grette, 2007). The modern vegetation around the lake can be characterized as arctic tundra consisting of lichen and herbaceous taxa (Lozhkin et al., 2007a). Around the high-relief slopes of the catchment basin this flora is often limited and discontinuous. The closest modern day forests lie $\sim 150 \mathrm{~km} \mathrm{SW}$ of the lake, occurring as light conifer forest (Lozhkin et al., 2007a).

\subsection{Chronology}

Sediment used by this study was taken from ICDP core 50111 (Fig. 1), extracted from Lake El'gygytgyn in 2009. Thirtynine samples were taken at varying depth intervals between $13.9 \mathrm{~m}$ and $20.7 \mathrm{~m}$ with each sample representing $\sim 500$ to $1000 \mathrm{yr}$. The composite core record was tuned from fixed tie points based on magnetostratigraphic investigations and the ages of magnetic reversals from Lisiecki and Raymo (2005), which has a reported error of $4 \mathrm{kyr}$ for the $0-1 \mathrm{Ma}$ interval. This work and synchronous tuning of 9 data sets between the magnetic tie points is reported in Melles et al. (2012). Due to a sediment slump feature in the ICDP core during MIS 10, the samples from MIS 11 (21 samples) were furthered shifted by approximately $\sim 2000 \mathrm{yr}$ to compensate for missing time in the sediment record, well within the error of the Lisiecki and Raymo (2005) benthic stack, and the Lake El'gygytgyn age models.

\subsection{Biomarkers}

Various classes of organic molecules (lipids) have been extensively studied and proven to be useful biomarkers due to their relative resistance to degradation and source specific molecular configurations (e.g. Eglinton and Hamilton, 1967; Volkman, 1986; Cranwell, 1973). In this paleolimnological study, the lipid compound classes of aliphatic hydrocarbons (n-alkanes), long chain 1,15 $n$-alkyl diols, sterols, pentacyclic triterpenes and glycerol dialkyl glycerol tetraethers (GDGTs) have been identified, quantified, and used to examine variability in terrestrial and aquatic community structures during MIS 9 and 11. Using records of these compound classes produced in and around Lake El'gygytgyn, we investigate the relationship between changes in chemical remains preserved in the lacustrine sedimentary record and climatic changes during this critical period of time.

Aliphatic hydrocarbons ( $n$-alkanes) are organic compounds derived from both autochthonous and allochthonous sources (e.g. Eglinton and Hamilton, 1967; Didyk et al., 1978; Meyers and Ishiwatari, 1993) and are widespread biomarkers in lacustrine sedimentary archives. The principal sources of biogenic aliphatic hydrocarbons to lake sediments are algae, bacteria and vascular plants that live within a lake, and vascular plants that live around it. These compounds are often used as recorders of local environmental changes. Short 


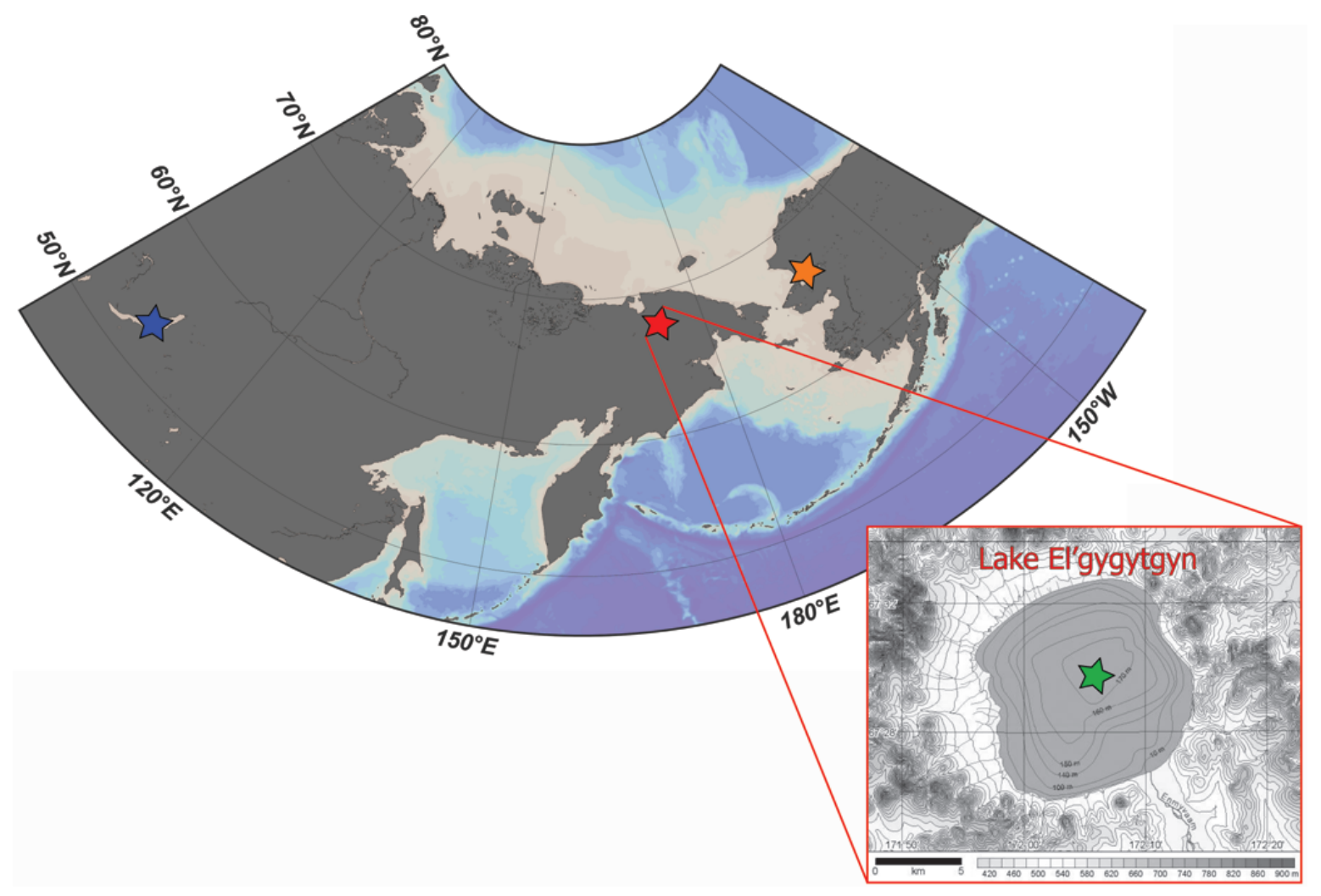

Fig. 1. Location of Lake El'gygytgyn (red star) and corresponding ICDP 5011-1 drill site (green star, inset map) are indicated. Other points of interest to this study and in the region are Lake Baikal (blue star) and the Baldwin Peninsula in Alaska (orange star).

chain $n$-alkanes $\mathrm{C}_{15}-\mathrm{C}_{21}$ (especially $\mathrm{C}_{17}$ ) are attributed to algae and photosynthetic bacteria (e.g. Cranwell et al., 1987; Meyers, 2003, and references therein), submerged and emergent aquatic plants are the main producers of mid-chain $\left(\mathrm{C}_{21}\right.$, $\mathrm{C}_{23}$, and $\mathrm{C}_{25}$ ) $n$-alkanes (Ficken et al., 2000), while longchain homologues $\left(\mathrm{C}_{25}-\mathrm{C}_{33}\right)$ are characteristic of higher order terrestrial plants (e.g. Eglinton and Hamilton, 1967; Cranwell et al., 1987). The $n$-alkane indices such as the Terrestrial to Aquatic Ratio (TAR) (Bourbonniere and Meyers, 1997) and the Carbon Preference Index (CPI) (Bray and Evans, 1961) (Table 1) can provide important constraints on the characteristic molecular distributions in each sample; these indices can reveal trends in the patterns and distributions of short-to-long carbon chain number and oddto-even carbon number predominance in the $n$-alkane profiles from our lake sediment samples. The $n$-alkane CPI can provide information on both preservation/degradation patterns in sedimentary records and/or source organism distributions helping to differentiate contributions from terrestrial, aquatic, and bacterial sources, with terrestrial sources usually showing the highest CPI values, followed by aquatic, and then bacterial sources (Bray and Evans, 1961; Eglinton and Hamilton, 1967). The $n$-alkane TAR index can provide useful information on organic matter (OM) sources, helping to distinguish the contributions of land-derived OM from that of aquatic sources, using the basic premise of carbon chain length variations specific to organism sources (Bourbonniere and Meyers, 1997).

Compounds such as sterols (and their saturated analogs, stanols) are useful biomarkers because carbon number, position of methyl groups, and double bonds in the molecule are indicative of certain groups of organisms (Volkman, 1986, 2003; Volkman et al., 1998). For example, dinoflagellate (Pyrrophyta) species are characterized by high concentrations of $4 \alpha$-methyl sterols with dinosterol $(4 \alpha, 23,24-$ trimethyl-5 $\alpha$-cholest-22-en- $3 \beta$-ol) as the main constituent in some species (Withers, 1983 1987). Additionally, dinosterol is not known to be produced from terrestrial sources and is relatively absent from other aquatic species (Volkman, 1986). However, it has been noted that dinosterol is not necessarily produced by all species of dinoflagellates (Rampen et al., 2010). Nevertheless, dinosterol has been extensively used as a biomarker for dinoflagellates (Castañeda and Schouten, 2011, and references therein), and is useful for examining past changes in dinoflagellate productivity (e.g. Castañeda et al., 2011).

The presence of long-chain $\left(\mathrm{C}_{28}-\mathrm{C}_{32}\right) \quad 1,15 n$-alkyl diols in lake sediments may indicate input from algae, as these compounds are common constituents of marine sediments where they are thought to be produced by Eustigmatophyte 
Table 1. Equations and indices used in this study.

\begin{tabular}{|c|c|c|}
\hline $\begin{array}{l}\text { Equations and } \\
\text { indices }\end{array}$ & Summary & Reference \\
\hline $\begin{array}{l}\text { Carbon Preference } \\
\text { Index }(\mathrm{CPI})\end{array}$ & $\mathrm{CPI}=\frac{\mathrm{C}_{23}+2 \cdot\left(\mathrm{C}_{25}+\mathrm{C}_{27}+\mathrm{C}_{29}+\mathrm{C}_{31}\right)}{\mathrm{C}_{33}+2 \cdot\left(\mathrm{C}_{24}+\mathrm{C}_{26}+\mathrm{C}_{28}+\mathrm{C}_{30}+\mathrm{C}_{32}\right)}$ & Bray and Evans (1961) \\
\hline $\begin{array}{l}\text { Terrigenous to Aquatic } \\
\text { Ratio (TAR) }\end{array}$ & $\mathrm{TAR}=\frac{\Sigma \mathrm{C}_{27}+\mathrm{C}_{29}+\mathrm{C}_{31}}{\Sigma \mathrm{C}_{17}+\mathrm{C}_{19}+\mathrm{C}_{21}}$ & $\begin{array}{l}\text { Bourbonniere and } \\
\text { Meyers (1997) }\end{array}$ \\
\hline $\begin{array}{l}\text { Average Chain Length } \\
\text { (ACL) }\end{array}$ & $\mathrm{ACL}=\frac{17\left(n \mathrm{C}_{17}\right)+19\left(n \mathrm{C}_{19}\right) \ldots 31\left(n \mathrm{C}_{31}\right)+33\left(n \mathrm{C}_{33}\right)}{n \mathrm{C}_{17}+n \mathrm{C}_{19} \ldots n \mathrm{C}_{31}+n \mathrm{C}_{33}}$ & $\begin{array}{l}\text { Modified from } \\
\text { Poynter and } \\
\text { Eglinton (1990) }\end{array}$ \\
\hline $\begin{array}{l}\text { Methylation of } \\
\text { Branched Tetraethers (MBT) }\end{array}$ & $\mathrm{MBT}=\frac{[\mathrm{I}]+[\mathrm{IIb}]+[\mathrm{Ic}]}{([\mathrm{II}]+[\mathrm{Ib}]+[\mathrm{Ic}])+([\mathrm{II}]+[\mathrm{II}]+[\mathrm{IIc}])+([\mathrm{III}]+[\mathrm{III}]+[\mathrm{IIIc}])}$ & Weijers et al. (2007b) \\
\hline $\begin{array}{l}\text { Cyclization of Branched } \\
\text { Tetraethers (CBT) }\end{array}$ & $\mathrm{CBT}=-\log \left(\frac{[\mathrm{Ib}]+[\mathrm{IIb}]}{[\mathrm{II}]+[\mathrm{II}]}\right)$ & Weijers et al. (2007b) \\
\hline $\begin{array}{l}\text { GDGT Specific MAAT } \\
\text { Calibration (Lake) }\end{array}$ & $\begin{array}{c}T\left({ }^{\circ} \mathrm{C}\right)=50.47-74.18 \cdot f \text { GDGT III }-31: 60 \cdot f \text { GDGT } \\
\text { II }-34: 69 \cdot f \text { GDGT I }\end{array}$ & Tierney et al. (2010) \\
\hline $\begin{array}{l}\text { GDGT Specific Summer } \\
\text { Temperature } \\
\text { Calibration (Lake) }\end{array}$ & $\begin{aligned} T\left({ }^{\circ} \mathrm{C}\right)=47.4- & (20.9 \cdot \mathrm{GDGT} \mathrm{I})-(37.1 \cdot \mathrm{GDGT} \text { II }) \\
& -(53.5 \cdot \mathrm{GDGT} \text { III })\end{aligned}$ & Pearson et al. (2011) \\
\hline $\begin{array}{l}\text { MBT/CBT MAAT } \\
\text { Calibration (Lake) }\end{array}$ & $T\left({ }^{\circ} \mathrm{C}\right)=6.803-7.062 \cdot \mathrm{CBT}+37.090 \cdot \mathrm{MBT}$ & Sun et al. (2011) \\
\hline $\begin{array}{l}\text { MBT Temperature } \\
\text { Calibration (Lake) }\end{array}$ & $T\left({ }^{\circ} \mathrm{C}\right)=55.01 \cdot \mathrm{MBT}-6.055$ & Zink et al. (2010) \\
\hline $\begin{array}{l}\mathrm{MBT}^{\prime} / \mathrm{CBT} \text { MAAT } \\
\text { Calibration (Soil) }\end{array}$ & $T\left({ }^{\circ} \mathrm{C}\right)=0.81-5.67 \cdot \mathrm{CBT}+31 \cdot \mathrm{MBT}^{\prime}$ & Peterse et al. (2012) \\
\hline $\begin{array}{l}\text { MBT/CBT MAAT } \\
\text { Calibration (Soil) }\end{array}$ & $T\left({ }^{\circ} \mathrm{C}\right)=11.84+32.54 \cdot \mathrm{MBT}-9.32 \cdot \mathrm{CBT}$ & Weijers et al. (2007b) \\
\hline
\end{tabular}

algae (Volkman et al., 1992, 1999; Versteegh et al., 1997; Rampen et al., 2007, 2008), although we note that other producers may exist in lakes (Castañeda and Schouten, 2011, and references therein). Long-chain $\left(\mathrm{C}_{28}-32\right) 1,15 n$-alkyl diols have been detected in a variety of marine and freshwater sediments (Castañeda et al., 2009, and references therein) and these compounds can be used to reconstruct aquatic primary productivity within lacustrine systems, which has been shown to have the potential for tracking climatic and environmental variability (Rampen et al., 2012).

Pentacyclic triterpenes and their respective derivatives such as arborinol (arbor-9(11)-en-3a-ol) are characteristic triterpenes of higher-order terrestrial vegetation (Albrecht and Ourisson, 1969; Vliex et al., 1994; Jacob et al., 2005). Specifically, arborinol has been extracted from the leaves of numerous species of trees, and can provide a record of changes in the extent of forest cover in an area (Jacob et al., 2005, and references therein).

Branched GDGTs (brGDGTs) are commonly found in soils and peats and are believed to be produced by anaerobic soil bacteria although the source organism(s) presently remains unknown (Weijers et al., 2007b). Acidobacteria are another possible source of brGDGTs in soils, as it has been shown that in laboratory cultures, some strains produce the brGDGT-I compound (Sinninghe Damsté et al., 2011). Changes in the degree of methylation (MBT) and cyclization (CBT) of branched GDGTs (Table 1) are a temperature and $\mathrm{pH}$ dependent process (Weijers et al., 2007b) and the MBT/CBT paleothermometer has been used to examine past continental temperature variability (e.g. Weijers et al., 2007a; Fawcett et al., 2011). The main source of brGDGTs to marine settings is generally fluvial transport and thus MBT/CBTderived temperatures can represent the mean annual air (soil) temperature of the river drainage (e.g. Weijers et al., 2007b). In lacustrine systems application of the MBT/CBT paleothermometer is not as straightforward (Castañeda and Schouten, 2011) as there is strong evidence that brGDGTs can also be produced in situ from within the water column (Peterse et al., 2009; Tierney and Russell, 2009; Sinninghe Damsté et al., 2009; Bechtel et al., 2010; Blaga et al., 2010; Tierney et al., 2012). Despite uncertainties pertaining to the origin of brGDGTs in lake sediments, several studies have applied the 
MBT/CBT paleothermometer to sediment cores to examine past temperature variability (e.g. Zink et al., 2010; Fawcett et al., 2011; Blaga et al., 2010). It should be noted that regional or lake specific calibrations are likely needed when applying the MBT/CBT paleothermometer to lakes (e.g. Tierney et al., 2010; Zink et al., 2010; Castañeda and Schouten, 2011) and without a site-specific calibration, MBT/CBT-derived temperatures should only be interpreted in terms of relative temperature change and not absolute temperatures.

\section{Methods}

\subsection{Sample extraction}

Thirty-nine sediment samples $(\sim 6-12 \mathrm{~g})$ were selected for molecular analyses at a coarse sampling resolution of $\sim$ one sample per $10 \mathrm{kyr}$ for the $200 \mathrm{kyr}$ study interval, which spans from 289 to $464 \mathrm{ka}$. Freeze dried, homogenized sediment samples were extracted with dichloromethane/methanol $(9: 1, \mathrm{v} / \mathrm{v})$ mixture at a temperature of $100^{\circ} \mathrm{C}$, using a Dionex automated solvent extractor (ASE). The results of this study represent processing of samples at different times using slightly different methods. For 26 of the samples, the total lipid extract was split in half and one half was separated into five fractions by silica-gel column-chromatography: (F1) aliphatic hydrocarbons (hexane), (F2) ketones (4:1 hexane:DCM, vol:vol), (F3) $n$-alkanols/sterols/stanols (9:1 DCM:acetone vol : vol), (F4) fatty acids ( $2 \%$ formic acid in DCM) and (F5) polar compounds (methanol). For the remaining half of the TLE from these 26 samples along with 13 additional samples, the TLE was separated into apolar (9:1 DCM: hexane, vol/vol), ketone (1:1 DCM: hexane, vol/vol) and polar (1:1 DCM:MeOH, vol/vol) fractions using alumina oxide column chromatography. One sample at $\sim 460 \mathrm{ka}(480 \mathrm{ka})$ was not included in the brGDGT analysis due to complications in laboratory procedures, however was processed for all other analyses. The $n$ alkanol/sterol/stanol fraction (F3) and the polar fractions from the first and second column schemes, were derivatized to their trimethylsilyl-ethers using bistrimethylsilyltrifluoroacetamide (BSTFA) with acetonitrile as a catalyst $(1: 1$, $\mathrm{V}: \mathrm{V})$ at $60-70^{\circ} \mathrm{C}$ for roughly one hour prior to $\mathrm{GC}$ analysis.

\subsection{Compound identification and quantification by GC and HC-MS}

Compound identification was performed using a Hewlett Packard 6890 series gas chromatograph (GC) - mass spectrometer equipped with a $5 \%$ phenyl methyl siloxane column (HP-5, $60 \mathrm{~m} \times 0.25 \mathrm{~mm} \times 0.25 \mu \mathrm{m})$. The GC-MS oven temperature program for running the F1/apolar and the F3/polar fractions initiated at $70^{\circ} \mathrm{C}$, increased at a rate of $20^{\circ} \mathrm{C} \mathrm{min}^{-1}$ to $130^{\circ} \mathrm{C}$ and then next increased at a rate of $4{ }^{\circ} \mathrm{C} \mathrm{min}^{-1}$ to $320^{\circ} \mathrm{C}$. The final temperature of $320^{\circ} \mathrm{C}$ was held for $20 \mathrm{~min}$.
Mass scans were made over the interval from 50 to $600 \mathrm{~m} / \mathrm{z}$. Compound identification was achieved by interpretation of characteristic mass spectra fragmentation patterns, gas chromatographic relative retention times, and by comparison with literature.

Quantification was performed using a Hewlett Packard 6890 series GC-Flame Ionization Detector (GC-FID) equipped with the same capillary column and using the same temperature program as described above. Compound concentrations were calculated by comparing integrated sample peak areas with the integrated peak areas of an added internal standard (hexatriacontane, the $\mathrm{C}_{37} n$-alkane).

\subsection{Compound identification and quantification by HPLC - MS}

Splits of the polar fractions were filtered through a $0.45 \mu \mathrm{m}$ PTFE syringe filter in 99: 1 hexane : propanol (vol/vol) and were subsequently analyzed on an Agilent 1260 HPLC coupled to an Agilent $6120 \mathrm{MSD}$, for identification and quantification GDGTs following the methods of Hopmans et al. (2000), with minor modifications (Schouten et al., 2007). A $\mathrm{C}_{46}$ GDGT was used as an internal standard. Separation was achieved on a Prevail Cyano column $(150 \mathrm{~mm} \times 2.1 \mathrm{~mm}$, $3 \mu \mathrm{m})$ using $99: 1$ hexane : propanol (vol: vol) as an eluent. After the first $7 \mathrm{~min}$, the eluent increased by a linear gradient up to $1.8 \%$ isopropanol (vol) over the next $45 \mathrm{~min}$ at a flow rate of $0.2 \mathrm{~mL} \mathrm{~min}^{-1}$. Scanning was performed in selected ion monitoring (SIM) mode.

\section{Results}

$\mathrm{C}_{28}, \mathrm{C}_{30}$ and $\mathrm{C}_{32} n$-alkyl 1, 15-diols are present in high concentrations during interglacial periods MIS 9 and 11 (Fig. 2b) with total concentrations (sum of $\mathrm{C}_{28}, \mathrm{C}_{30}$ and $\mathrm{C}_{32} 1,15 n$ alkyl diols) ranging from 1.16 to $20.17 \mu \mathrm{g} \mathrm{g}_{\text {sed }}^{-1}$ and average concentrations of 9.30 and $16.25 \mu \mathrm{g} \mathrm{g}_{\text {sed }}^{-1}$ for MIS 9 and 11 , respectively. During glacial periods long-chain $1,15 n$-alkyldiols are present in low concentrations (Fig. 2b), with total concentrations ranging from 0.92 to $4.97 \mu \mathrm{g} \mathrm{g}_{\text {sed }}^{-1}$ and averages of $2.22,1.39$ and $3.01 \mu \mathrm{g} \mathrm{g}_{\text {sed }}^{-1}$ for MIS 8,10 and 12 , respectively.

Dinosterol concentrations show a similar overall trend to those of the long-chain 1,15n-alkyl-diols, with relatively high average concentrations of 3.18 and $4.08 \mu \mathrm{gg}_{\text {sed }}^{-1}$ during respective interglacial stages 9 and 11 (Fig. 2d), while present in very low concentrations during glacial periods with average concentrations of $0.38,0.41$ and $0.57 \mu \mathrm{g} \mathrm{g}_{\text {sed }}^{-1}$ for MIS 8, 10 and 12, respectively. Arborinol concentrations are highest during interglacial periods (MIS 9 and 11; Fig. 2c) varying in concentration between 1.69 and $28.53 \mu \mathrm{g} \mathrm{g}_{\text {sed }}^{-1}$ with an average concentration of 13.57 and $21.63 \mu \mathrm{g} \mathrm{g}_{\text {sed }}^{-1}$ during MIS 9 and 11, respectively. Arborinol concentrations drop off rapidly during interglacial to glacial transitions, and are 


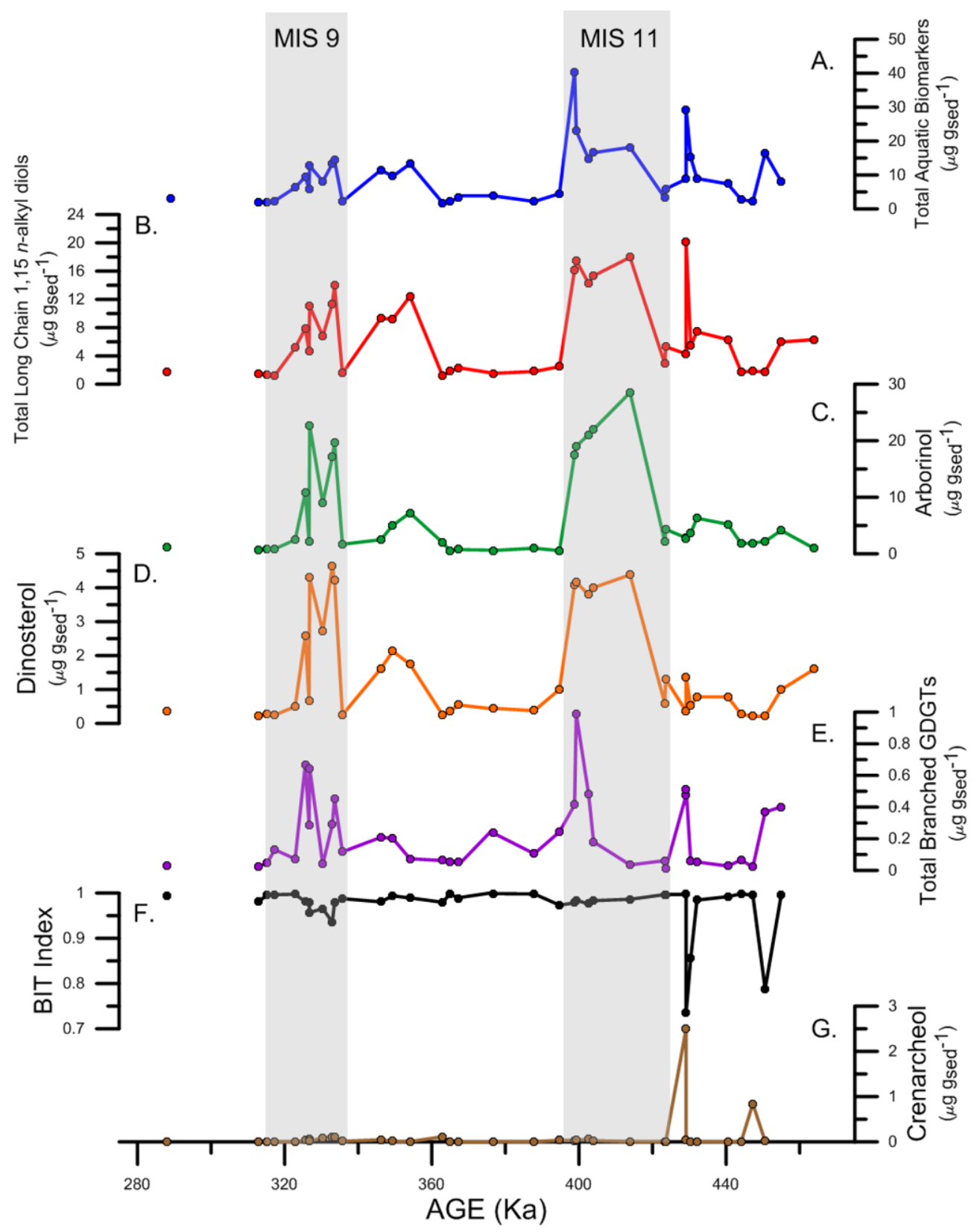

Fig. 2. (a through g) Calculated and measured organic geochemical proxies for the period of $275 \mathrm{Ka}$ to $475 \mathrm{Ka}$ for (a) total aquatic biomarkers, defined as the $\Sigma\left[\mathrm{C}_{17}\right]+\left[\mathrm{C}_{19}\right]+\left[\mathrm{C}_{21}\right]+[$ dinosterol $]+\left[\Sigma\right.$ long chain $\left(\mathrm{C}_{28}, \mathrm{C}_{30}, \mathrm{C}_{32}\right)$ n-alkyl diols $]$; (b) sum of long chain $\left(\mathrm{C}_{28}, \mathrm{C}_{30}, \mathrm{C}_{32}\right)$ 1, $15 n$-alkyl diols; (c) arborinol $\left(\mu \mathrm{g} \mathrm{g}_{\mathrm{sed}}^{-1}\right)$; (d) dinosterol $\left(\mu \mathrm{g} \mathrm{g}_{\mathrm{sed}}^{-1}\right)$. (e) Concentrations of total branched GDGTs $\left(\mu \mathrm{g} \mathrm{g}_{\text {sed }}^{-1}\right)$; (f) BIT index; (g) crenarchaeol $\left(\mu \mathrm{g} \mathrm{g}_{\mathrm{sed}}^{-1}\right)$. Gray bars indicate the timing of MIS 9 and MIS 11 interglacial periods.

below detection limits during most of the glacial periods (MIS 8, 10, and 12) varying between 0 and $4.14 \mu \mathrm{g} \mathrm{g}_{\text {sed }}^{-1}$ with an average concentration of $1.69 \mu \mathrm{g} \mathrm{g}_{\text {sed }}^{-1}$ for all glacial periods.

Branched GDGT concentrations range from 0.09 to $0.99 \mu \mathrm{gg}_{\mathrm{sed}}^{-1}$ and on average are more abundant during interglacial periods (Fig. 2e). MBT/CBT derived temperature estimates range from -9.2 to $3.0^{\circ} \mathrm{C}$ when applying the global soils calibration of Weijers et al. (2007b) and from -3.5 to $6.4^{\circ} \mathrm{C}$ when applying the $\mathrm{MBT}^{\prime} / \mathrm{CBT}$ soils calibration of Peterse et al. (2012). Using other published lacustrine calibrations, the temperatures range from 6.7 to $16.5^{\circ} \mathrm{C}$ (Tierney et al., 2010), 8.1 to $17.9^{\circ} \mathrm{C}$ (Pearson et al., 2011), 1.4 to $13.4^{\circ} \mathrm{C}$ (Sun et al., 2011) and 0.2 to $9.8^{\circ} \mathrm{C}$ (Zink et al., 2010) (Fig. 3a-f). The lowest temperature according to the Weijers et al. (2007b) calibration is noted at $440 \mathrm{ka}$ 


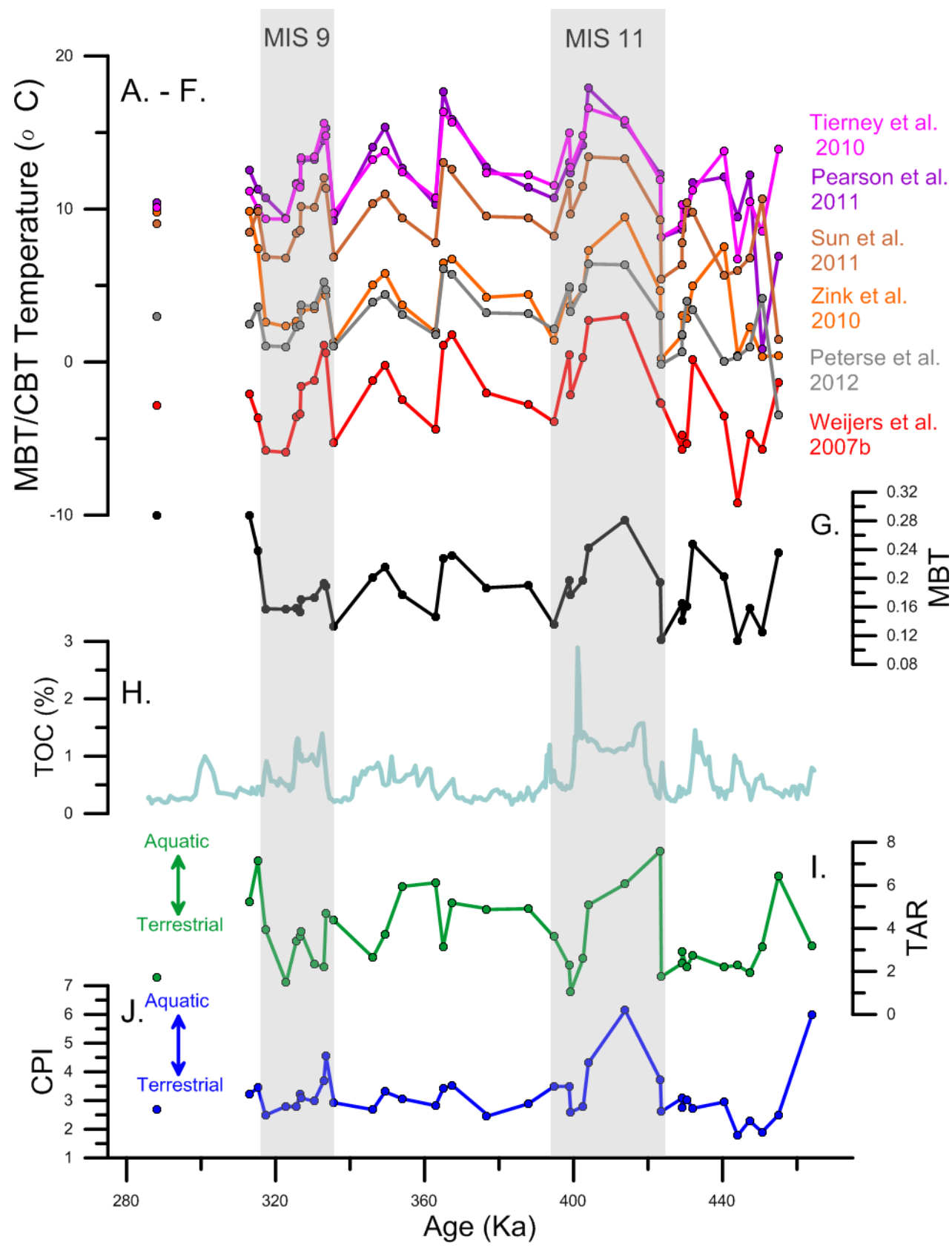

Fig. 3. (a through j) MBT/CBT Temperature $\left({ }^{\circ} \mathrm{C}\right)$ calculated from brGDGTs based on calibrations of (a) Weijers et al. (2007b); (b) Tierney et al. (2010); (c) Pearson et al. (2011); (d) Sun et al. (2011); (e) Zink et al. (2010) and (f) Peterse et al. (2012). (g) MBT values; (h) TOC data; (i) TAR values, where the arrow indicates increased terrestrial input and (j) CPI values, where the arrow indicates increased terrestrial input and/or OM preservation. Gray bars indicate the timing of MIS 9 and MIS 11 interglacial periods.

(MIS 12) while the highest value occurs $\sim 25 \mathrm{kyr}$ later, at $415 \mathrm{ka}$ (MIS 11).

Carbon numbers for $n$-alkanes range from $\mathrm{C}_{17}$ to $\mathrm{C}_{35}$. Carbon-preference index values $(\mathrm{CPI})$ for $\mathrm{C}_{23}$ to $\mathrm{C}_{33}$ $n$-alkanes show values between 1.8 and 6.1 for all sample depths, with an average of $3.1 \pm 0.7$ (Fig. 3j). The terrestrial to aquatic $n$-alkane ratio (TAR) has values between 1.07 and 7.59, with an average value of 3.72 (Fig. 3i). The carbon number with the maximum abundance varies considerably between samples, with some samples having bimodal distributions peaking at $\mathrm{C}_{17}$ and $\mathrm{C}_{27}, \mathrm{C}_{29}$, or $\mathrm{C}_{31}$, and others showing a monomodal distribution with a single maximum at $\mathrm{C}_{27}, \mathrm{C}_{29}$ or $\mathrm{C}_{31}$. Average chain lengths (ACL) (Poynter and Eglinton, 1990) range from 25 to 28 (not plotted) but do not show distinct patterns between all glacial and interglacial periods. 


\section{Discussion}

Previous studies of Lake El'gygytgyn point toward both a global and regional response of the lake environment to various climate forcings (Lozhkin et al., 2007a, b; Melles et al., 2007, 2012). A record of pollen counts and diatom productivity (the latter inferred from the $\mathrm{Si} / \mathrm{Ti}$ record as shown by Melles et al., 2012; Fig. 4d) shows the highest terrestrial and aquatic productivity during MIS 11, while MIS 9 is characterized by slightly diminished productivity relative to MIS 11 (Melles et al., 2012). The overall paleo-environmental record presented here corroborates past work, and our results further elucidate subtle differences in ecological community structure and productivity during MIS 9 and MIS 11. Temperatures recorded by the MBT/CBT paleothermometer are often correlated strongly with other biogeochemical proxy records of terrestrial vegetation changes and aquatic productivity, showing a clear response of each to local temperature variability during interglacial-glacial transitions as well as within interglacial periods. Biogeochemical proxy records also show a high degree of correlation with various other paleorecords such as those from continental Asia (Lake Baikal), the Bering Sea, the North Atlantic, and Antarctica, indicating an integrated global response (Fig. 4, cf. Vogel et al., 2012).

\subsection{Biogeochemical records and normalization}

The percent of total organic carbon (\%TOC) may be used as a proxy for primary productivity in lakes (Meyers and Ishiwatari, 1993, 1995; Meyers, 1997) although TOC in lacustrine sediments represents contributions from both autochthonous and allochthonous sources. Overall \% TOC values in Lake El'gygytgyn are low and range from 0.1-3\% over the interval of study, reflecting the monomictic oligotrophic to ultra-oligotrophic nature of the lake (Melles et al., 2012). Interestingly, we note that the response of TOC in Lake El'gygytgyn during Quaternary glacial and interglacial periods is not consistent throughout the record (Fig. 3g), and the mechanisms behind this variability are not well characterized. An example of the variable nature of the TOC record occurs during the MIS 2 glacial period, where \%TOC is much higher than during the two surrounding interglacial periods, MIS 1 and 3 (Holland et al., 2013). The TOC data from MIS 9 and 11 reveal a somewhat contrasting response with slightly elevated TOC values during MIS 11 in comparison to the surrounding glacials, MIS 10 and 12 (Fig. 3g). However, TOC data from MIS 9 cannot readily be demarcated from the surrounding interglacials MIS 8 and 10, as they are all characterized by relatively similar values. In contrast, all other biological based proxies from Lake El'gygytgyn (i.e. biogenic silica) clearly show elevated values corresponding to interglacial periods throughout the Pleistocene, including MIS 9 and 11 (Fig. 4h), making them easily discernible from the surrounding glacial periods. Although normalizing biogeochemical data to grams of organic carbon using \% TOC values is a common method to investigate the effects of preservation vs. production on biomarker concentrations, the nature of TOC data in Lake El'gygytgyn, especially during MIS 9 and 11, prevents the confident use of the TOC data to normalize the biomarker data. Ongoing organic geochemical research suggests that the non-solvent extractable portion of TOC varies considerably, and independently of glacial-interglacial cycles, at Lake El'gygytgyn. As such, the biomarker concentration data is normalized to g sediment extracted $\left(\mathrm{g}_{\mathrm{sed}}^{-1}\right)$.

\subsection{Preservation of Organic Matter}

The CPI is often used to examine preservation of OM, yet the relationship between $n$-alkane CPI values and degradation is less clear in aquatic environments due to the weaker odd over even preference of bacteria and aquatic algae (Grimalt and Albaiges, 1987) that results in lower CPI values compared to terrestrial OM (Cranwell et al., 1987). OM in aquatic sediments is usually considered substantially degraded when CPI values are below 1 (Bray and Evans, 1961) Because CPI values of $n$-alkanes (1.8-6.1) are higher than 1 throughout this record (avg $=3.1 \pm 0.7)$, and there are no observable trends in decreasing CPI down-core, progressive OM biodegradation through time is likely to be limited in this record. However, it has been proposed that the bottom waters of Lake El'gygytgyn become anoxic/suboxic during various glacial periods, in which case OM degradation may have had a greater influence on the preservation of $\mathrm{OM}$ in the lake throughout glacial-interglacial transitions (Holland et al., 2013). During interglacial periods (MIS 9 and 11) the CPI record exhibits the highest values, which quickly drop off to significantly lower values as the record transitions to glacial periods (MIS 8, 10 and 12). This trend can be attributed to either a decrease in biodegradation of OM during interglacial periods or it otherwise may represent an increase in terrestrial OM input. However, based on our records we do not have the necessary information to designate the relative amounts either of these mechanisms may have had on the observed trends in CPI and OM preservation.

\subsection{Temperature variability}

Relative temperature changes at Lake El'gygytgyn were examined using the MBT/CBT paleothermometer by applying several different calibrations (Weijers et al., 2007b; Tierney et al., 2010; Zink et al., 2010; Pearson et al., 2011; Sun et al., 2011; Peterse et al., 2012) (Fig. 3a-f). We note that without a modern calibration set and without knowing if the main source of brGDGTs in Lake El'gygytgyn is from within the lake or the watershed, it is not clear which of the presently available MBT/CBT calibrations is the most suitable to apply. It has been suggested that site specific or regional calibrations may be needed for MBT/CBT and 


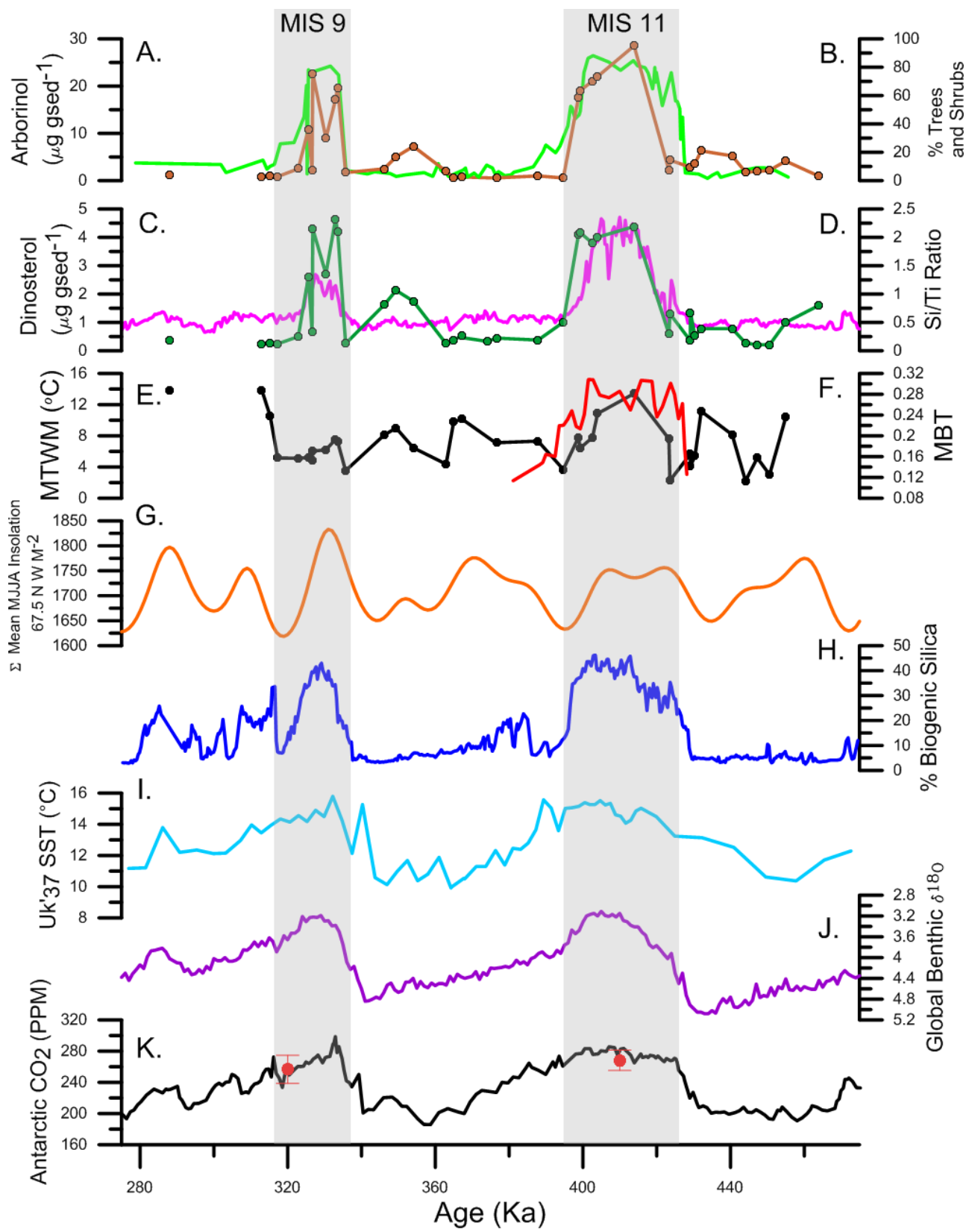

Fig. 4. (a through k) (a) Measured arborinol concentrations ( $\mu \mathrm{g} \mathrm{g}_{\mathrm{sed}}^{-1}$ ) (brown line and points) with (b) measured tree pollen counts (green line) (from Lozhkin and Anderson, 2013; Lozhkin et al., 2007b); (c) dinosterol ( $\mu \mathrm{g} \mathrm{g}_{\mathrm{sed}}^{-1}$ ) (green points and line), compared with (d) Si/Ti ratio (red line) from Melles et al. (2012); (e) calculated mean temperature of the warmest month (Melles et al., 2012) with (f) calculated MBT ratio. (g) The sum of insolation from May, June, July and August (MJJA) from Laskar et al. (2004); (h) the Lake Baikal biogenic silica record (Prokopenko et al., 2007); (i) North Atlantic sea surface temperature (SST) record from alkenones ( $\mathrm{U}_{37}^{K^{\prime}}$ ) from Lawrence et al. (2009); (j) global benthic Foraminifera $\delta^{18} \mathrm{O}$ stack from Lisiecki and Raymo (2005); and (k) atmospheric $\mathrm{CO}_{2}$ concentrations measured from the EPICA Antarctic Ice Core (EPICA Community Members, 2004), with red dots indicating average $\mathrm{CO}_{2}$ concentrations for the MIS 9 and MIS 11 interglacial periods. Gray bars indicate the timing of MIS 9 and MIS 11 interglacial periods.

other factors such as a seasonal production maximum of brGDGTs should be evaluated for individual sites (Castañeda and Schouten, 2011). We note modern air temperatures at this site span from -40 to $+26^{\circ} \mathrm{C}$, with a mean annual air temperature of $-10.3^{\circ} \mathrm{C}$ (Nolan and Brigham-Grette, 2007). Water temperatures within the lake are always below $4^{\circ} \mathrm{C}$, although shallow shelf areas can reach up to $5^{\circ} \mathrm{C}$ in summer (Nolan and Brigham-Grette, 2007). Palynological data 
from Lake El'gygytgyn sediment cores has been previously used to calculate the mean temperature of the warmest month (MTWM) based on terrestrial vegetation pollen assemblage abundances over the MIS 11 to MIS 12 transition, and reveal a $\sim 12{ }^{\circ} \mathrm{C}$ relative temperature change during this period (Melles et al., 2012). Furthermore, temperature estimates from diatom $\delta^{18} \mathrm{O}$ (Chapligin et al., 2012) suggest interglacial to glacial changes of $\sim 9{ }^{\circ} \mathrm{C}$, both of which support interglacial to glacial temperature changes which are similar to ranges reported from the multiple MBT/CBT reconstructions. Yet given the wide range of temperatures noted in and around the lake, all of the currently available MBT/CBT calibrations to temperature could be feasible, especially if seasonal biases are considered. Therefore, at present, absolute temperatures as recorded by MBT/CBT cannot be reconstructed with confidence at Lake El'gygytgyn. Noteably, MBT/CBT indices shown in Fig. 3a and b are similar to the MTWM index compiled by Tarasov in Melles et al. (2012).

In marine settings, the Branched and Isoprenoid Tetraether (BIT) Index (Hopmans et al., 2004) provides a proxy for soil organic matter versus aquatic input and is based on a ratio of relative abundances of brGDGTs to crenarchaeol, a biomarker of aquatic thaumarchaeota (formerly crenarchaeota). BIT index values range from 0 to 1 , with an aquatic end member value of 0 indicating an aquatic end member in which crenarchaeol is the only compound present, while a value of 1 represents pure soil OM source (Hopmans et al., 2004). However, in lakes the interpretation of BIT index values is not as straightforward as brGDGTs likely also derive from within the water column (Peterse et al., 2009; Tierney and Russell, 2009; Sinninghe Damsté et al., 2009; Bechtel et al., 2010; Blaga et al., 2010; Tierney et al., 2012). At Lake El'gygytgyn, BIT values are quite high and range from 0.74 to 0.99 (Fig. 2f) during MIS 8 to 12 but are driven mainly by variations in crenarchaeol concentrations rather than by variations in inputs of brGDGTs. Lower BIT index values (Fig. 2f) correlate to intervals when increased concentrations of crenarchaeol are noted (Fig. 2g).

For the reasons stated above, we strongly caution readers against interpreting Lake El'gygytgyn MBT/CBT derived temperatures either in terms of absolute temperatures or the overall amplitude of the temperature signal. However, relative temperature changes from the MBT/CBT record are presented and show varying degrees of correspondence with summer insolation for $67.5^{\circ} \mathrm{N}$ (Fig. 4f). A comparison to local insolation (Laskar et al., 2004) shows some similarities, suggesting that MBT/CBT-derived temperatures could represent a signal of summer temperature, a concept previously proposed by Pearson et al. (2011), although some of the differences between the MBT/CBT record and insolation could arise as a result of the large uncertainties inherent in the age model used. Furthermore, the MBT/CBT temperatures demonstrate changes resembling interstadial periods MIS 11.b and MIS 9.b (Fig. 3a-f), which is indicative of the potential sensitivity of the MBT/CBT method. Yet, given the sampling resolution of this study, interglacial subdivisions are speculative and merely resemble subdivision made in previous studies (Lisiecki and Raymo, 2005). Higher resolution analyses for this interval are required before further interpretations can be made, but the $30 \mathrm{ka}$ duration of the MIS 11 interglacial shown by Prokopenko et al. (2010) in Lake Baikal records is nevertheless evident in our record. During the MIS 10 glacial period, MBT/CBT-derived temperature estimates are anomalously high in three of the samples (Fig. 3a-f). The high variability exhibited in samples from the MIS 10 is not well understood, although variability in summer insolation is a possible explanation. Hao et al. (2013) also demonstrate a weakening of the East Asian winter monsoon, and therefore a weaker Siberian High, during MIS 10. This weakening would result in persistent non glacial conditions during MIS 10 based on records from the Chinese Loess Plateau, providing a different potential mechanism for the warmth recorded by the MBT/CBT proxy at this time.

\subsection{Vegetation change}

During the MIS 11 interglacial, values for the $n$-alkane indices (CPI and TAR) suggest OM in the sediment is largely from terrestrial sources, a trend that is corroborated by tree pollen records and high arborinol concentrations (Fig. 2c), suggesting forestation of the lake catchment (Melles et al., 2012; Lozhkin and Anderson, 2013). This is likely a result of increased sensitivity of terrestrial vegetation in Arctic regions, as a drop in temperature can easily cause permanent snow and nivation hollows to form, killing off most terrestrial vegetation, while submerged aquatic plants and bacteria can continue to thrive as long as sunlight can still penetrate the ice-cover (Melles et al., 2007). The interpretations made from the $n$-alkane CPI record are further supported by the $n$ alkane TAR proxy, revealing changes in the amount of OM being delivered from terrigenous or aquatic sources. Mean $n$-alkane TAR values suggest higher overall terrestrial contributions in MIS 11.

Following peak warmth at $415 \mathrm{ka}$, vegetation records based on arborinol concentrations and pollen data exhibit a gradual decrease in terrestrial vegetation, especially after the drop in temperature at $\sim 400 \mathrm{ka}$ (MIS 11.b) before the onset of MIS 10 (Fig. 4a and b). During the glacial interval at $\sim 395 \mathrm{ka}$, arborinol concentrations are at or below the detection limit, indicative of the return of tundra plant cover and/permanent snow cover.

The response of the terrestrial and aquatic communities to MIS 9 is somewhat weaker from that of MIS 11, supporting previous observations by Melles et al. (2012) that MIS 11 was a "super interglacial" period. Biomarker data from MIS 9 indicate a clear interval of warmth (Figs. 2-4). Early in MIS 9, warmer interglacial MBT/CBT-derived temperatures suggest that the terrestrial community may have experienced full forestation, supported by the high concentrations 
of arborinol, and low CPI values during this time period ( 325 to $335 \mathrm{ka}$ ). Pollen records from the MIS 9 time period (Lozhkin et al., 2007b), together with the record of arborinol, indicates MIS 9 overall was a weaker interglacial than MIS 11. The highest terrestrial productivity based on the $\mathrm{Si} / \mathrm{Ti}$ ratio also coincides with the period of peak MIS 9 warmth as recorded by the MBT/CBT record, indicating the growth of trees and shrubs with warmer temperatures (Figs. 3 and 4).

Possible explanations for the vegetation differences include variability of both summer insolation and $\mathrm{CO}_{2}$ during MIS 9 and 11 (Laskar et al., 2004; EPICA Community Members, 2004). Although peak $\mathrm{CO}_{2}$ and insolation values are both highest in MIS 9, MIS 11 records indicate slightly lower yet less variable $\mathrm{CO}_{2}$ and insolation values. These stable forcings could have resulted in the higher vegetation response; otherwise this could have also resulted from changes in preservation, if for instance, there was increased anoxia during MIS 11. Although records from later glacial periods such as the Last Glacial Maximum (MIS 2) show higher TOC and biomarker concentrations than interglacials (MIS 1 and 3) (Holland et al., 2013), recent work has also demonstrated that OM preservation/degradation during MIS 2 is an anomalous interval, for the period spanning 0 to $1.2 \mathrm{Ma}$ (Snyder et al., 2012). Therefore, MIS 2 may not serve as a good analog for other interglacial and glacial period from deeper parts of the Lake El'gygytgyn record.

\subsection{Aquatic productivity}

At Lake El'gygytgyn, stable and warm temperatures during interglacials could have allowed for increased aquatic productivity and diversity, a point corroborated by high concentrations of the aquatic biomarkers of long-chain 1, $15 n$-alkyldiols, dinosterol, and diatom productivity as indicated by the lake Si/Ti ratio proxy (Melles et al., 2012). These increases in biomarker concentrations may also reflect increases in the preservation of organic matter due to changes in dynamics of the lake operating system as a response to climatic changes (Snyder et al., 2012). During peak MIS 11 (420 to $400 \mathrm{ka}$ ), the concentrations of the aquatic biomarkers reach the highest values of the record (Fig. 2a), which correspond with a period (418.5 to $402 \mathrm{ka}$ ) of peak warmth and precipitation determined by Vogel et al. (2012). At the $400 \mathrm{ka}$ temperature drop recorded by MBT/CBT, CPI values decrease rapidly, and slight decreases in long-chain 1,15n-alkyldiols and dinosterol concentrations are evident (Fig. 2b). Following this temperature drop, our biomarker records indicate a rebound in the dinoflagellate and algal communities, with higher productivity prior to the onset of MIS 10 while $\mathrm{Si} / \mathrm{Ti}$ ratios (an indicator of diatom productivity) fail to recover. The lack of diatoms and high concentrations of dinosterol and long-chain 1, $15 n$-alkyl-diols points to biological niche conditions where decreasing temperatures are coincident with less diversity of primary producers in the lake water, as opposed to peak MIS 11 warm conditions where the lake supports a diverse aquatic community of primary producer organisms. While our records do not show evidence for a strong glacial-interglacial change in the preservation of OM in Lake El'gygytgyn, it is possible that preservation during glacial versus interglacial periods is in fact different. If so, biomarker concentrations in our records may show biases based on preservation rates, especially when making glacial to interglacial comparisons (Holland et al., 2013).

We searched for the compounds loliolide, isololiolide, gorgesterol, fucoxanthin, and various methyl-cholesterol compounds, all of which have been used as molecular indicators for the presence of different diatom species communities (Rampen et al., 2010). Despite biogenic silica records indicating the presence of a substantial diatom community in Lake El'gygytgyn, thus far, we have been unable to identify any of these diagnostic molecular markers in our sediment samples.

\subsection{MIS 9 and 11 interglacial comparisons}

Overall, biomarker records indicate high temperatures during MIS 11.c, and warm temperatures during MIS 9 as suggested by the MBT/CBT paleothermometer. As such, the climate both of MIS 11.c and MIS 9 supported a diverse range of organisms, including high productivity of terrestrial plants as well as high numbers of diatoms, dinoflagellates, and algal organisms (cf. Snyder et al., 2012). The transition from interglacial to glacial periods is marked by a dramatically sharp decline in long chain 1, $15 n$-alkyl diols (Fig. 2b), indicating that a critical threshold was reached.

Following MIS 10 glaciation, GDGT temperatures show evidence for a single warm periods occurring during MIS 9 (Fig. 3). Temperatures during early MIS 9 reveal a warm peak associated with increased diatom, algal, and terrestrial productivity. The aquatic community is similar to the MIS 11 peak, where high concentrations of all aquatic markers, abundant diatoms and an increase in sediment accumulation rates were measured (Snyder et al., 2012; Cunningham et al., 2012). The record of long-chain $\left(\mathrm{C}_{28}-\mathrm{C}_{32}\right) 1,15 n$-alkyl diols suggests elevated contributions from eustigmatophyte algae as well, although these compounds are not present at the higher values measured for MIS 11. Early MIS 9 resembles the community structure of late MIS 11 following the 400 ka temperature drop where diatom abundance decreased but dinoflagellate levels remained high. Recorded changes in aquatic productivity are similar to our records of terrestrial vegetation variability, and the two demonstrate a high degree of correlation (Fig. 2a). In this sense, aquatic productivity further substantiates how the lake and catchment area has responded to stable versus more variable climate forcings in the past. 


\subsection{Global context}

Orbital parameters vary notably between MIS 11 and MIS 9 (Yin and Berger, 2010), as evident in the July insolation curve at $67.5^{\circ} \mathrm{N}$ (Laskar et al., 2004) (Fig. 4g). Discrepancies in local insolation during these periods are one possible mechanistic explanation for the observed variability of local temperatures estimated by the MBT/CBT index. Yet during these two interglacial periods there are also differences in global atmospheric concentrations of $\mathrm{CO}_{2}$, with average concentrations at $\sim 260 \mathrm{ppm}$ and $270 \mathrm{ppm}$ during MIS 9 and 11, respectively (EPICA Community Members, 2004). The slightly higher and more stable average atmospheric concentrations of global $\mathrm{CO}_{2}$ during MIS 11 present a possible mechanism behind the distinctively warm and stable conditions that characterize the MIS 11 interglacial period in our records even though total insolation is less than that of MIS 9 by $\sim 20 \mathrm{~W} \mathrm{~m}^{-2}$ (Laskar et al., 2004). While MIS 9 peak atmospheric $\mathrm{CO}_{2}$ levels were higher than during MIS 11 (Luthi et al., 2008), the stability and duration of elevated $\mathrm{CO}_{2}$ concentrations during MIS 11 results in higher average $\mathrm{CO}_{2}$ concentrations. Melles et al. (2012) proposed that evidence for a collapsed Greenland ice sheet (Raymo and Mitrovica, 2012) and higher sea levels during MIS 11.c could allow for increased throughflow of warm water into the Arctic Ocean through the Denmark Strait, Fram Strait and Bering Strait, modulating warm conditions in the Russian Arctic.

Detailed changes in the local ecology of the lake and surrounding catchment observed in our records supports the labeling of MIS 11.c as a "super interglacial", as its diverse and abundant organism community is not matched in MIS 9, which demonstrates stronger summer insolation forcing (cf. Vogel et al., 2012). Additionally, reconstructions of global ice volume and bottom water temperatures from benthic Foraminifera during this time period (Lisiecki and Raymo, 2005) display notable similarities, specifically a warmer and longer MIS 11.c as compared to MIS 9. Records from Lake Baikal indicate a particularly long MIS 11 (Prokopenko et al., 2010), suggesting connections in the climate system over the Asian continent. Comparison of our biomarker record to the Lake Baikal biogenic silica record also shows a similar pattern and response to summer insolation. Additionally, in the Bering Sea, increased percentages of warm water diatom species, as well as decreased abundances of sea ice species, further indicate the ubiquitous warmth characteristic of this time period (Caissie, 2012).

While the temperature estimates made from the MBT/CBT index also record the stable, peak warmth of MIS 11, our reconstructions also reveal considerable variability absent in many records of global signals. For instance, temperature decreases noted at $\sim 400 \mathrm{ka}$ during MIS 11 and at $\sim 325 \mathrm{ka}$ during MIS 9 are not recorded in globally averaged records such as benthic Foraminifera stacks. Initial comparisons of the $400 \mathrm{ka}$ temperature drops with mid-latitude Atlantic Ocean records indicate the onset of MIS 11.b interstadial was demonstrated by a flux of ice rafted debris and a drop in $\delta^{18} \mathrm{O}$-based North Atlantic surface temperatures (Voelker et al., 2010). Additionally, alkenone $\left(\mathrm{U}_{37}^{k^{\prime}}\right)$ sea surface temperatures in the North Atlantic (Lawrence et al., 2009) demonstrate a similar temperature decrease suggesting these events were not isolated to Lake El'gygytgyn. Evidence for early glacial inception from central Beringia suggests that at this time, the Arctic regions were beginning to cool with small changes in insolation (Huston and Brigham-Grette, 1990; Brigham-Grette, 2001). Diatom assemblages in the Bering Sea also indicate cooler conditions, with increased percentages of sea ice species during this interval $\sim 400 \mathrm{ka}$ (Caissie, 2012). Although sea level was high (Raymo and Mitrovica, 2012) the presence of glacio-marine sediments overlain by till indicates the advance of glaciers coincident with the $\sim 400$ ka temperature drop (Huston and Brigham-Grette, 1990). During the mid-stage MIS 9 interstadial (9.b), changes in the Lake Baikal biogenic silica (Prokopenko et al., 2007) record can be roughly aligned with MBT/CBT temperature estimates as well (Fig. 4). The response of the Lake El'gygytgyn record to these changes indicates the lake is sensitive to these global and regional changes, and thus is not solely recording local climate conditions.

\section{Conclusions}

Biomarker investigation allows for the reconstruction of not only temperatures based on the MBT/CBT paleothermometer, but also a semi-quantitative analysis of both terrestrial and aquatic productivity in the lake during MIS 11 and MIS 9. Results from this study corroborate the long duration of MIS 11 warmth of $\sim 30 \mathrm{kyr}$ found in Lake Baikal by Prokopenko et al. (2010) and in ice core records (EPICA Community Members, 2004). In concert with the long duration, the MIS 11 "super interglacial" interpretation by Melles et al. (2012) is supported by our results, with a diverse aquatic community indicated by high concentrations of all measured biomarkers. The overall record of MIS 9 and MIS 11 agrees with other records from various global locations as well, linking the Lake El'gygytgyn record to the global climate system. However, to further understand the ecological changes indicated by the biomarkers, future work must involve higher resolution sampling and analysis in addition to calibrations of the MBT/CBT paleothermometer so that absolute temperature may be reconstructed. Nonetheless, the results of this study indicate these biomarkers can provide critical information about paleo-ecological conditions, and shed light on how these climate changes are reflected in sensitive environments from Arctic regions. 
Acknowledgements. Funding for this research was provided by the International Continental Scientific Drilling Program (ICDP), the US National Science Foundation (NSF), the German Federal Ministry of Education and Research (BMBF), Alfred Wegener Institute (AWI) and GeoForschungsZentrum Potsdam (GFZ), the Russian Academy of Sciences Far East Branch (RAS FEB), the Russian Foundation for Basic Research (RFBR), and the Austrian Federal Ministry of Science and Research (BMWF). The Russian GLAD 800 drilling system was developed and operated by DOSECC Inc., the downhole logging was performed by the ICDP-OSG, and LacCore, at the University of Minnesota, handled core curation. Raw pollen data for was provided by Anatoly Lozhkin, NEISRI, and Patricia Anderson, University of Washington. We especially acknowledge NSF support for grant \# EAR-0602471.

Edited by: D.-D. Rousseau

\section{References}

Albrecht, P. and Ourisson, G.: Triterpene Alcohol isolation from Oil Shale, Science, 163, 1192-1193, 1969.

Bechtel, A., Smittenberg, R. H., Bernasconi, S. M., and Schubert, C. J.: Distribution of branched and isoprenoid tetraether lipids in an oligotrophic and a eutrophic Swiss lake: insights into sources and GDGT-based proxies, Org. Geochem., 41, 822-832, 2010.

Blaga, C. I., Reichart, G. J., Schouten, S., Lotter, A. F., Werne, J. P., Kosten, S., Mazzeo, N., Lacerot, G., and Sinninghe Damsté, J. S.: Branched glycerol dialkyl tetraethers in lake sediments: Can they be used as temperature and $\mathrm{pH}$ proxies?, Org. Geochem., 41, 1225-1234, 2010.

Bourbonniere, R. A. and Meyers, P. A.: Sedimentary geolipid records of historical changes in the watersheds and productivities of Lakes Ontario and Erie, Limnol. Oceanogr., 41, 352-359, 1997.

Bray, E. E. and Evans, E. D.: Distribution of n-paraffins as a clue to recognition of source beds, Geochim. Cosmochim. Ac., 22, 2-15, 1961.

Brigham Grette, J.: New perspectives on Beringian Quaternary paleogeography, stratigraphy, and glacial history, Quaternary Sci. Rev., 20, 15-24, 2001.

Caissie, B. E.: Diatoms as recorders of Sea Ice in the Bering and Chukchi seas: Proxy development and application, PhD Dissertation, Univeristy of Massachusetts Amherst, 1-164, 2012.

Castañeda, I. S. and Schouten, S.: A review of molecular organic proxies for examining modern and ancient lacustrine environments, Quaternary Sci. Rev., 30, 2851-2891, doi:10.1016/j.quascirev.2011.07.009, 2011.

Castañeda, I. S., Werne, J. P., and Johnson, T. C.: Influence of climate change on algal community structure and primary productivity of Lake Malawi (East Africa) from the Last Glacial Maximum to present, Limnol. Oceanogr., 54, 2431-2447, 2009.

Castañeda, I. S., Werne, J. P., Johnson, T. C., and Powers, L. A.: Organic geochemical records from Lake Malawi (East Africa) of the last $700 \mathrm{yr}$, part II: biomarker evidence for recent changes in primary productivity, Palaeogeogr. Palaeocl., 303, 140-154, 2011.

Chapligin, B., Meyer, H., Swann, G. E. A., Meyer-Jacob, C., and Hubberten, H.-W.: A $250 \mathrm{ka}$ oxygen isotope record from di- atoms at Lake El'gygytgyn, far east Russian Arctic, Clim. Past, 8, 1621-1636, doi:10.5194/cp-8-1621-2012, 2012.

Cranwell, P. A.: Chain length distribution of n-alkanes from lake sediments in relation to post-glacial environmental change, Freshwater Biol., 3, 259-265, 1973.

Cranwell, P. A., Eglinton, G., and Robinson, N.: Lipids of aquatic organisms as potential contributors to lacustrine sediments - II, Org. Geochem., 11, 513-527, 1987.

Cunningham, L., Vogel, H., Wennrich, V., Juschus, O., Nowaczyk, N., and Rosén, P.: Amplified bioproductivity during Transition IV (332000-342000 yr ago): evidence from the geochemical record of Lake El'gygytgyn, Clim. Past Discuss., 8, 5341-5358, doi:10.5194/cpd-8-5341-2012, 2012.

Didyk, B. M., Simoneit, B. R. T., Brassell, S. C., and Eglinton, G.: Organic geochemical indicators of paleoenvironmental conditions of sedimentation, Nature, 272, 216-222, 1978.

Eglinton, G. and Hamilton, R. J.: Leaf epicuticular waxes, Science, 156, 1322-1335, 1967.

Epica Community Members: Eight glacial cycles from an Antarctic ice core, Nature, 429, 623-628, 2004.

Fawcett, P. J., Werne, F. P., Anderson, R. S., Heikoop, J. M., Brown, E. T., Berke, M. A., Smith, S. J., Goff, F., Donohoo-Hurley, L., Cisneros-Dozal, L. M., Schouten, S., Sinnighe Damsté, J. S., Huang, Y., Toney, J., Fressenden, J., WoldeGabriel, G., Atudorei, V., Geissman, J. W., and Allen, C. D.: Extended megadroughts in the southwestern United States during Pleistocene interglacials, Nature, 470, 518-521, 2011.

Ficken, K. J., Li, B., Swain, D. L., and Eglinton, G.: An n-alkane proxy for the sedimentary input of submerged/floating freshwater aquatic macrophytes, Org. Geochem., 31, 745-749, 2000.

Grimalt, J. and Albaiges, J.: Sources and occurrence of $\mathrm{C}_{12}-$ $\mathrm{C}_{22} n$-alkanes distributions with even carbon-number preference in sedimentary environments, Geochim. Cosmochim. Ac., 51, 1379-1384, 1987.

Hao, Q., Wang, L., Oldfield, F., Peng, S., Qin, L., Song, Y., Xu, B., Qiao, Y., Bloemendal, J., and Guo, Z.: Delayed build-up of Arctic ice sheets during 400,000-year minima in insolation variability, Nature, 490, 393-396, 2013.

Holland, A., Wilkie, K. M., Petsch, S. T., Burns, S. J., Castañeda, I. S., Brigham-Grette, J., and El'gygytgyn Scientific Party: Using bulk and compound specific isotope analysis to explore connections between episodic isotope depletion and anoxia at Lake El'gygytgyn, Far East Russian Arctic, Clim. Past Discuss., in preparation, 2013.

Hopmans, E. C., Schouten, S., Pancost, R. D., van der Meer, M. T. J., and Sinninghe Damsté, J. S.: Analysis of intact tetraether lipids in archaeal cell material and sediments by high performance liquid chromatography/atmospheric pressure chemical ionization mass spectrometry, Rapid Commun. Mass Sp., 14, 585-589, 2000.

Hopmans, E. C., Weijers, W. H. J., Schefuß, E., Herfort, L., Sinninghe Damsteé, J. S., and Schouten, S.: A novel proxy for terrestrial organic matter in sediments based on branched and isoprenoidtetraether lipids, Earth Planet. Sc. Lett., 224, 107-116, 2004.

Huston, M. M. and Brigham-Grette, J.: Paleogeographic significance of Middle Pleistocene glaciomarine deposits on Baldwin Peninsula, Northwest Alaska, Ann. Glaciol., 14, 111-119, 1990. 
Jacob, J., Disnar, J. R., Boussafir, M., Sifeddine, A., Albuquerque, A. L. S., and Turcq, B.: Pentacyclic triterpene methyl ethers in recent lacustrine sediments (Lagoa do Caçó, Brazil), Org. Geochem., 36, 449-46, 2005.

Laskar, J., Robutel, P., Joutel, F., Gastineau, M., Correia, A. C. M., and Levrard, B.: A long-term numerical solution for the insolation quantities of the Earth, Astron. Astrophys., 428, 261-285, 2004.

Lawrence, K. T., Herbert, T. D., Brown, C. M., Raymo, M. E., and Haywood, A. M.: High Amplitude Variations in North Atlantic Sea Surface Temperature During the Early Pliocene Warm Period, Paleoceanography, 24, PA2218, doi:10.1029/2008PA001669, 2009.

Layer, P. W.: Argon-40/argon-39 age of the El'gygytgyn impact event, Chukotka, Russia, Meteorit. Planet. Sci., 35, 591-599, 2000.

Lisiecki, L. E. and Raymo, M.: A Pliocene-Pleistocene stack of 57 globally distributed benthic $\delta^{18} \mathrm{O}$ records, Paleoceanography, 20, PA1003, doi:10.1029/2004PA001071, 2005.

Loutre, M. F. and Berger, A.: Marine Isotope Stage 11 as an analogue for the present interglacial, Global Planet. Change, 36, 209-217, 2002

Lozhkin, A. V. and Anderson, P. M.: Vegetation responses to interglacial warming in the Arctic, examples from Lake El'gygytgyn, northeast Siberia, Clim. Past Discuss., 9, 245-267, doi:10.5194/cpd-9-245-2013, 2013.

Lozhkin, A. V., Anderson, P. M., Matrosova, T. V., and Minyuk, P. S.: The pollen record from El'gygytgyn Lake: implications for vegetation and climate histories of norther Chukotka since the late middle Pleistocene, J. Paleolimnol., 37, 135-153, 2007 a.

Lozhkin, A. V., Anderson, P. M., Matrosova, T. V., Minyuk, P. S., Brigham-Grette, J., and Melles, M.: Continuous record of environmental changes in Chukotka during the last 350 thousand years, Russ. J. Pac. Geol., 1, 550-555, 2007b.

Luthi, D., Le Floch, M., Bereiter, B., Blunier, T., Barnola, J.-C., Siegenthaler, U., Raynaud, D., Jouzel, J., Fischer, H., Kawamura, K., and Stocker, T. F.: High-resolution carbon dioxide concentration record 650,000-800,000 years before present, Nature, 453, 379-382, 2008.

Melles, M., Brigham-Grette, J., Glushkova, O. Y., Minyuk, P. S., Nowaczyk, N. R., and Hubberton, H.-W.: Sedimentary geochemistry of core PG131 from Lake El'gygytgyn - a sensitive record of climate variability in the East Siberian Arctic during the past three glacial-interglacial cycles, J. Paleolimnol., 37, 89-104, 2007.

Melles, M., Brigham-Grette, J., Minyuk, P. S., Nowaczyk, N. R., Wennrich, V., DeConto, R. M., Anderson, P. M., Andreev, A. A., Coletti, A., Cook, T. L., Haltia-Hovi, E., Kukkonen, M., Lozhkin, A. V., Rosen, P., Tarasov, P., Vogel, H., and Wagner, B.: 2.8 Million Years of Arctic Climate Change from lake El'gygytgyn, NE Russia, Science, 337, 315-320, 2012.

Meyers, P. A.: Organic geochemical proxies of paleooceanographic, paleolimnologic, and paleoclimatic processes, Org. Geochem., 27, 213-250, 1997.

Meyers, P. A.: Applications of organic geochemistry to paleolimnological reconstructions: a summary of examples from the Laurentian Great Lakes, Org. Geochem., 34, 261-289, 2003.

Meyers, P. A. and Ishiwatari, R.: The early diagenesis of organic matter in lacustrine sediments, in: Organic Geochemistry: Prin- ciples and Applications, edited by: Engels, M. H. and Macko, S. A., 185-209, Plenum Press, New York, 1993.

Meyers, P. A. and Ishiwatari, R.: Organic matter accumulation records in lake sediments, in: Physics and Chemistry of Lakes, edited by: Lerman, A., Imboden, R., and Gat, J., 279-289, Springer-Verlag, New York, 1995.

Nolan, M.: Analysis of local AWS and NCEP/NCAR reanalysis data at Lake El'gygtytgyn, and its implications for maintaining multi-year lake-ice covers, Clim. Past Discuss., 8, 1443-1483, doi:10.5194/cpd-8-1443-2012, 2012.

Nolan, M. and Brigham-Grette, J.: Basic hydrology, limnology, and meteorology of modern Lake El'gygytgyn, Siberia, J. Paleolimnol., 37, 17-35, 2007.

Pearson, E. J., Juggins, S., Talbot, H. M., Weckström, J., Rosén, P., Ryves, D. B., Roberts, S. J., and Schmidt, R.: A lacustrine GDGT-temperature calibration from the Scandinavian Arctic to Antarctic: Renewed potential for the application of GDGTpaleothermometry in lakes, Geochim. Cosmochim. Ac., 75, 6225-6238, 2011

Peterse, F., Kim, J. H., Schouten, S., Kristensen, D. K., Kos, N., and Sinninghe Damsté, J. S.: Constraints on the application of the MBT/CBT palaeothermometer at high latitude environments (Svalbard, Norway), Org. Geochem., 40, 692-699, 2009.

Peterse, F., van der Meer, J., Schouten, S., Weijers, W. H. J., Fierer, N., Jackson, R. B., Kim, J. H., and Sinninghe Damsté, J. S.: Revised calibration of the MBT-CBT paleotemperature proxy based on branched tetraether membrane lipids in surface soils, Geochim. Cosmochim. Ac., 96, 215-229, 2012.

Poynter, J. G. and Eglinton, G.: Molecular composition of three sediments from hole 717C: The Bengal Fan, in: Proceedings of the Ocean Drilling Program Scientific Result, edited by: Cochran, J. R., Stow, D. A. V., Stewart, N. J., Barbu, E. M., Mazullo, E. K., Stewart, S. K., and Winkler, W. R., 116, 155-161, 1990.

Prokopenko, A. A., Hinnov, L. A., Williams, D. F., and Kuzmin, M. I.: Orbital forcing of continental climate during the Pleistocene: a complete astronomically tuned climatic record from Lake Baikal, SE Siberia, Quaternary Sci. Rev., 25, 3431-3457, 2007.

Prokopenko, A. A., Bezrukova, E. V., Khursevich, G. K., Solotchina, E. P., Kuzmin, M. I., and Tarasov, P. E.: Climate in continental interior Asia during the longest interglacial of the past 500000 years: the new MIS 11 records from Lake Baikal, SE Siberia, Clim. Past, 6, 31-48, doi:10.5194/cp-6-31-2010, 2010.

Rampen, S. W., Schouten, S., Wakeham, S. G., and Sinninghe Damsté, J. S.: Seasonal and spatial variation in the sources and fluxes of long chain diols and mid-chain hydroxy methyl alkanoates in the Arabian Sea, Org. Geochem., 38, 165-179, 2007.

Rampen, S. W. , Schouten, S., Koning, E., Brummer, G.-J. A., and Sinninghe Damste, J. S.: A $90 \mathrm{kyr}$ upwelling record from the northwestern Indian Ocean using a novel long-chain diol index, Earth Planet. Sc. Lett., 276, 207-213, 2008.

Rampen, S. W., Abbas, B. A., Schouten, S., and Sinninghe Damsté, J. S.: A comprehensive study of sterols in marine diatoms (Bacillariophyta): implications for their use as tracers for diatom productivity, Limnol. Oceanogr., 55, 91-105, 2010.

Rampen, S. W., Willmott, V., Kim, J.-H., Uliana, E., Mollenhauer, G., Schefuß, E., Sinninghe Damsté, J. S., and Schouten, S.: Long chain 1,13- and 1,15-diols as a potential proxy for palaeotemperature reconstruction, Geochim. Cosmochim. Ac., 84, 204-216, 
2012.

Raymo, M. E. and Mitrovica, J. X.: Collapse of polar ice sheets during the stage 11 interglacial, Nature, 483, 453-456, 2012.

Schouten, S., Huguet, C., Hopmans, E. C., Kienhuis, M. V. M., and Sinninghe Damste, J. S.: Analyticalmethodology for TEX86 paleothermometry by high-performance liquid chromatography/atmospheric pressure chemical ionization-mass spectrometry, Anal. Chem., 79, 2940-2944, 2007

Sinninghe Damsté, J. S., Ossebaar, J., Abbas, B., Schouten, S., and Verschuren, D.: Fluxes and distribution of tetraether lipids in an equatorial African lake: constraints on the application of the TEX 86 paleothermometer and BIT index in lacustrine settings, Geochim. Cosmochim. Ac., 73, 4232-4249, 2009.

Sinninghe Damsté, J. S., Rijpstra, W. I. C., Hopmans, E. C., Weijers, W. H., Foesel, B. U., Overmann, J., and Dedysh, S. N.: 13,16-dimethyl octacosanedioic acid (iso-diabolic acid), a common membrane-spanning lipid of Acidobacteria subdivisions 1 and 3, Appl. Environ. Microb., 12, 4147-4154, 2011.

Snyder, J. A., Cherepanova, M. V., and Bryan, A.: Dynamic diatom response to changing climate 0-1.2 Ma at Lake El'gygytgyn, far east Russian Arctic, Clim. Past Discuss., 8, 4601-4624, doi:10.5194/cpd-8-4601-2012, 2012.

Sun, Q., Chu, G., Liu, M., Xie, M., Li, S., Ling, Y., Wang, X., Shi, L., Jia, G., and Lü, H.: Distributions and temperature dependence of branched glycerol dialkyl glycerol tetraethers in recent lacustrine sediments from China and Nepal, J. Geophys. Res., 116, G01008, doi:10.1029/2010JG001365, 2011.

Tierney, J. E. and Russell, J. M.: Distribution of branched GDGTs in a tropical lake system: implications for the application of the MBT/CBT proxy, Org. Geochem., 40, 1032-1036, 2009.

Tierney, J. E., Russell, J. M., Eggermont, H., Hopmans, E. C., Verschuren, D., and Sinninghe Damsté, J. S.: Environmental controls on branched tetraether lipid distributions in tropical East African lake sediments, Geochim. Cosmochim. Ac., 74, 49024918, 2010.

Tierney, J. E., Schouten, S., Pithcer, A., Hopmans, E. C., and Sinninghe Damsté, J. S.: Core and intact polar glycerol dialkyl glycerol tetraethers (GDGTs) in Sand Pond, Warwick, Rhode Island (USA): Insights into the origin of lacustrine GDGTs, Geochim. Cosmochim. Ac., 77, 561-581, 2012.

Versteegh, G. J. M., Bosch, H.-J., and de Leeuw, J. W.: Potential palaeoenvironmental information of $\mathrm{C}_{24}$ to $\mathrm{C}_{36}$ mid-chain diols, keto-ols and mid-chain hydroxy fatty acids; a critical review, Org. Geochem., 27, 1-13, 1997.

Vliex, M., Hagemann, H. W., and Püttmann, W.: Aromatized arborane/fernane hydrocarbons as molecular indicators of floral changes in Upper Carboniferous/Lower Permian strata of the Saar-Nahe Basin, southwest Germany, Geochim. Cosmochim. Ac., 58, 4689-4702, 1994.

Voelker, A. H. L., Rodrigues, T., Billups, K., Oppo, D., McManus, J., Stein, R., Hefter, J., and Grimalt, J. O.: Variations in midlatitude North Atlantic surface water properties during the midBrunhes (MIS 9-14) and their implications for the thermohaline circulation, Clim. Past, 6, 531-552, doi:10.5194/cp-6-531-2010, 2010 .
Vogel, H., Meyer-Jacob, C., Melles, M., Brigham-Grette, J., Andreev, A. A., Wennrich, V., and Rosén, P.: Detailed insight into Arctic climatic variability during MIS 11 at Lake El'gygytgyn, NE Russia, Clim. Past Discuss., 8, 6309-6339, doi:10.5194/cpd8-6309-2012, 2012.

Volkman, J. K.: A review of sterol markers for marine and terrigenous organicmatter, Org. Geochem., 9, 83-99, 1986.

Volkman, J. K.: Sterols in microorganisms, Appl. Microbiol. Biot., 60, 495-506, 2003.

Volkman, J. K., Barrett, S. M., Dunstan, G. A., and Jeffrey, S. W.: $\mathrm{C}_{30}-\mathrm{C}_{32}$ alkyl diols and unsaturated alcohols in microalgae of the class Eustigmatophyceae, Org. Geochem., 18, 131-138, 1992.

Volkman, J. K., Barrett, S. M., Blackburn, S. I., Mansour, M. P., Sikes, E. L., and Gelin, F.: Microalgal biomarkers: a review of recent research developments, Org. Geochem., 29, 1163-1179, 1998.

Volkman, J. K., Rijpstra, W. I. C., de Leeuw, J. W., Mansour, M. P., Jackson, A. E., and Blackburn, S. I.: Sterols of four species of dinoflagellates from the genus Prorocentrum, Phytochemistry, 52, 659-668, 1999.

Weijers, J. W. H., Schefuß, E., Schouten, S., and Sinninghe Damsté, J. S.: Coupled thermal and hydrological evolution of tropical Africa over the last deglaciation, Science, 315, 1701-1704, 2007a.

Weijers, J. W. H., Schouten, S., van den Donker, J. C., Hopmans, E. C., and Sinninghe Damsté, J. S.: Environmental controls on bacterial tetraether membrane lipid distribution in soils, Geochim. Cosmochim. Ac., 71, 703-713, doi:10.1016/j.gca.2006.10.003, 2007b.

Withers, N.: Dinoflagellate Sterols, in: Marine Natural Products: Chemical and Biological Perspectives, Vol. 5, edited by: Scheuer, P. J., Academic Press, New York, 87-130, 1983.

Withers, N.: Dinoflagellate sterols, in: The Biology of Dinoflagellates, Vol. 21, edited by: Taylor, F. J. R., Blackwell Scientific, Oxford, 316-359, 1987.

Yin, Q. Z. and Berger, A.: Insolation and $\mathrm{CO}_{2}$ contribution to the interglacial climate before and after the Mid-Bruhnes Event, Nat. Geosci., 3, 243-246, 2010.

Zink, K. G., Vandergoes, M. J., Mangelsdorf, K., DieffenbacherKrall, A. C., and Schwark, L.: Application of bacterial glycerol dialkyl glycerol tetraethers (GDGTs) to develop modern and past temperature estimates from New Zealand lakes, Org. Geochem., 41, 1060-1066, 2010. 